\title{
Reflections
}

\section{Reflections on the variations and spatialities of (un)welcome - commentary to Gill}

\author{
JANI VUOLTEENAHO AND EVELIINA LYYTINEN
}

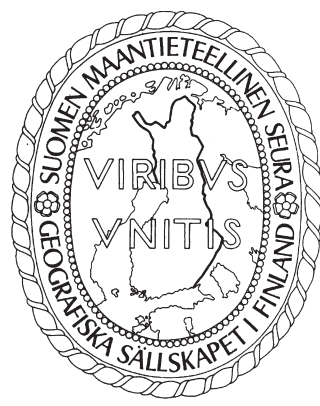

Vuolteenaho, J. \& Lyytinen, E. (2018) Reflections on the variations and spatialities of (un)welcome - commentary to Gill. Fennia 196(1) 118-123. https://doi.org/10.11143/fennia.70290

In this reflection, we seek to develop some of Professor Gill's inspiring ideas on the notion of (un)welcome further. We do this, in particular, by problematizing his largely dualistic conception of the emotionallyinvested, inter-personal forms of welcome contra a bureaucratic tendency to abstract welcome, to hollow it out emotionally. We argue that if applied too rigidly, this dichotomy can be unwieldy for making sense of the actual socio-spatial and emotional dynamics of (un)welcome. To elaborate this criticism, we expand on the notion of welcome from three interrelated perspectives. First, we argue that besides the opposite poles of people who welcome refugees, and forces that attempt to exclude them, great many actors convey more ambiguous and contextually varying attitudes to (un)welcoming immigrants. In the light of Lefebvre's conceptual triad of social space, we next point out that Gill's conceptualization pays inadequate heed to the practiced and societally recompensing aspects of everyday spatiality and welcoming. Finally, we take a cue from Gill's suggestion to analyze welcome from the emotional geographies perspective, and reflect on exclusionary and inclusionary socio-spatial processes related to refugees' emotions (lived space) and coping tactics (practiced space).

Keywords: variations of welcome, lived space, practiced space, emotional geographies, refugees

Jani Vuolteenaho, Department of Geography and Geology, University of Turku, Fl-20014, Turku, Finland. E-mail: jani.vuolteenaho@utu.fi

Eveliina Lyytinen, The Migration Institute of Finland, Eerikinkatu 34, 20100 Turku,Finland.E-mail: evlyyt@utu.fi

\section{Introduction}

In the contemporary European context of the so-called refugee crisis, who is being welcomed by whom, and how are these acts of welcome increasingly suppressed? More generally, what conceptual, practical and emotional processes characterise the acts of welcoming in our societies? These conceptually challenging, ethically significant, and societally acute issues were brought into relief by Professor Nick Gill's keynote lecture at the annual Geography Days in Turku in October 2017.

Across Europe and beyond, as Gill notes $(2018,93)$, not only the operation of terrorists to unsettle people's sentiments of trust and solidarity, but also a broader "set of circumstances and 
governmentalities have created the conditions for the suppression of welcome as an inter-personal ethic" in recent years. All this has occurred despite a spate of grassroots organizations and activists who, while fighting intolerant attitudes, are delivering material and social support to the displaced people newly entered or attempting to enter Europe. We find key interpretations by Gill on these tension-filled processes as sobering, and also agree that researching the complexities of (un)welcome in the context of European refugee situation warrants the use of emotion-sensitive, ethically sound (usually qualitative) methodologies. Further, we strongly sympathize with his propositions on what could be done better in sustaining welcome particularly in circumstances where both calculated bureaucratic responses and xenophobic hate speech by right-wing extremists are increasingly questioning welcoming attitudes as idealistic.

Notwithstanding these and other merits in Gill's brief intervention, in our commentary we wish to highlight certain difficulties in his conceptualizations that in our view emanate from an excessively bipolarized conception of the emotionally-invested, inter-personal forms of welcome as a domain of spontaneity and genuineness contra a bureaucratic tendency to abstract welcome, to hollow it out emotionally. In particular, we point out that this type of dichotomizing can be unwieldy for making sense of the actual socio-spatial and emotional dynamics of (un)welcome.

To elaborate this criticism, we expand on the notion of welcome from three interrelated perspectives in this paper. First, we point out certain empirical exceptions and theoretical limitations to the picture of "people welcome, regimes do not" that is canvassed in a somewhat too rigid fashion in Gill's paper. Second, we draw from the concept of spatial practice by Lefebvre (1974 [1991]) to posit that the routinized and largely taken-for-granted but simultaneously societally recompensing aspects of everyday spatiality are mainly side-lined in Gill's conceptualization of emotions and (un)welcoming. Finally, we combine the Lefebvrian framework with Gill's ideas on the emotionally and geographically co-constituted nature of welcome by discussing the actual lived and practiced spaces where refugees' emotional repertoire is manifested.

\section{Decentring the dichotomy, or notes on the wavering majority}

As justifiably underscored by Gill, recent years in Europe have witnessed a considerably increased number of activists struggling for refugees' material sustenance and social inclusion. At the other extreme, there is the rise of anti-immigrant sentiments and movements with their populist right-wing rhetoric of vilifying the victims (a worrying global trend also touched upon in Gill 2018). To be sure, these welcoming and unwelcoming camps have lately become very vociferous players in political and media rows over how (in)tolerantly newcomers are or ought to be treated. While the opposite poles in focus have undoubtedly gained in popularity, it nonetheless seems justified to remark that neither adamantly anti- nor pro-refugee stances have grown hegemonic among native populations in the majority of European societies. While more research on the topic is needed, we surmise that most "ordinary" people (and even many politicians insofar as their unofficial personal mindsets are concerned) are actually "wobbling" when it comes to their opinions about (un)welcoming marginalized immigrants (cf. a study on the Finnish youth at the turn of the millenium: Suurpää 2002) - all this despite (or perhaps because of) bipolarized discussions and "alternative truths" excessively circulated in social and mass media discourses. At least in Finland, it seems likely that such attitudinal hesitancy or ambiguity reflects people's cautious tactics of self- and other positioning in varying interactional contexts of their everyday lives.

Given the above complexity, a poststructuralism-inspired critique would surely hold Gill's keynote complicit in drawing a simplifying binary between the genuinely humane acts of welcome, and the calculated abstractions of bureaucratic machineries devoid of compassion for human suffering. To dismantle this dichotomy, one might apply Foucault $(1990,96)$ and posit that the discourses of welcome and unwelcome "traverse social stratifications and individual unities" and alter contingent upon the constellations of power and social positionalities in particular discursive situations. An intriguing case in point is the sitting Finnish Prime Minister (PM) Sipilä, who during the heat of the socalled refugee crisis in September 2015 publically announced that asylum seekers could reside at his home in Kempele, North-Western Finland. In this unusually spontaneous and personally engaged 
attempt of welcome by a nationally outstanding politician, Sipilä also appealed his compatriots that "the asylum seekers deserve a human treatment and genuine welcome greeting from us Finns" (The Washington Post 2015). As one might expect, the PM's generous offer hit news headlines internationally (Reuters 2015). It was subsequently interpreted by some asylum seekers as a literal signal that Finland, as a country, was a welcoming destination. In due course, however, Sipilä had to retreat from his welcoming gesture; arguably due to security reasons his home was not opened to asylum seekers. This signalled a drastic turn from Sipilä's personal welcome address, to the institutional actions and discourse of unwelcome in months and years to come. As a matter of fact, Sipilä's cabinet, including a right-wing populist party, soon commenced a series of legal amendments and policy restrictions regarding international protection in Finland. As soon as by the end of 2015, the Government action plan on asylum policy (Finnish Government 2015) stated that the Finnish government, led by PM Sipilä, aims to make Finland a less attractive destination country for asylum seekers. ${ }^{1}$

Despite the exceptionality of Sipilä's welcome, it highlights ambiguities and context-dependencies of stance-taking towards refugees across affluent European populations and many policy-makers alike. In our view, such ambiguities should be taken into account when conceptualizing and analyzing the spatialities of the discourses, practices and emotions invested in (un)welcoming. At the same time, however, we contend that a fully poststructuralist approach (insisting on theoretical grounds in the indeterminacy of identity positions) would risk profound ethical problems in study contexts concerning the (un)welcoming of asylum seekers and other displaced people. In lieu of anti-humanist poststucturalist approaches to welcome, there fortunately exists fecund critical theorizations more akin to the ethos of Gill's intervention, one of which is outlined by Lefebvre, a theorist to whom also Gill himself refers.

\section{Further spatialities of (un)welcome à la Henri Lefebvre}

According to Gill (2018), both the genuine acts of welcome and bureaucratic procedures of suppressing them are inherently spatial. More specifically, Gill argues that the spaces of welcome are both lived and abstract referring the French social theorist and critical urban thinker Lefebvre's (1974 [1991]) analysis of the production of space. Similarly drawing from Lefebvre's classic triad of socio-spatial theory, our second reflection is that in order to understand welcome, we need to deliberate its discursively "conceived" (in the Lefebvrian-Foucauldian sense), "lived" and "perceived" (practiced) spatial aspects. As for the theoretically or technocratically conceived space (synonymous in Lefebvre's terminology with representations of space that tend to abstract features and relations acted out in concrete spaces), Gill $(2018,92)$ rightly notes that abstract ways of conceiving socio-spatial realities carry with them a risk that "the representations are used to dominate and dictate reality". Needless to stress, this smacks of an all too truthful depiction of multiple European settings where the concrete acts of welcoming refugees, asylum seekers and above all deportees have been increasingly restricted and even criminalized.

By contrast, according to Lefebvre (1974 [1991]) another distinct dimension of social space is space "fully lived" through emotional experiences, memories, symbols and feelings of belonging and nonbelonging, fears and fantasies, hopes for justice and utopian wishes for a better life (e.g. Shields 1999). As many critical geographers have accentuated, lived space is often enacted "as resistance to representations of abstract space" (McDowell \& Sharp 1999, 33), or through "counter-discourses that have either escaped the purview of bureaucratic power or manifest a refusal to acknowledge its authority" (Butler 2012, 5). Also this Lefebvre-inspired understanding is centrally present in Gill's conceptualization of the emotion-charged spatiality of welcome and its rationalistic-bureaucratic counter-forces, and rightly so in our opinion.

Adding the sociological and indeed geographical insightfulness of his conceptual triad, Lefebvre (1974 [1991]) further conceptualizes spatial practice (perceived or commonsensical space) as the societally recompensing ways of operating (through employment, volunteering, consuming etc.) available for people a given society. Practically perceived via a lens of everyday tasks and more or less routinized roles that individuals perform in their distinct ways, the socio-culturally learned spatial practices not only secure the normalized functioning of the society, but also afford each society 
member with varying degrees of what Lefebvre (1974 [1991], 38, 288-289) dubs as "spatial competence" (see also Vuolteenaho 2001, 2010; Merrifield 2006, 110-111). It seems to us that these routinely practiced aspects of social spatiality are largely missing from Gill's analytical apparatus, with the exception of his notions on hospitality as an institutionalized sphere associated with externally imposed duties and rights rather than with genuinely inner emotions (cf. a classic book on emotional labour and commercialized forms of welcome: Russell Hochschild 1983).

Be it as it may, it is important for the emotionally-focused scholarship on refugees and forced migrants to not to ignore the practiced aspects of spatiality in the Lefebvrian sense. To what extent are refugees aloof from the local functioning of the mainstream society, and how this affects their emotions (see e.g. Marshall et al. 2016)? For refugee scholars keen on the emotional geographies perspective (Davidson et al. 2005), refugees' spatial coping tactics, and how their integration may happen through spatially enacted and societally sanctioned positions and roles, open a whole array of burning research directions.

\section{Aliens in an alien country? On refugees' lived and practiced emotional geographies}

In refugee studies, emotions are often discussed with regard to the emotional repertoire of refugees during their diverse and deeply spatial experiences of fleeing and living in exile. This is significant for "narratives of migration are emotional stories of complex entanglements of feelings, experiences and imaginations" (Christou 2011, 252). Migration invariably affects emotions (Boccagni \& Baldassar 2015, 75), perhaps even more so for forced migrants (e.g. asylum seekers and refugees). Munt $(2012,556)$ vividly evokes the powerfully emotional experience of becoming a refugee as follows:

"Imagine a person who has suffered enforced migration, abruptly escaping from situations of terror - war, persecution, famine - as she arrives as an alien in an alienating country, stripped out of support (emotional, physical, legal and financial), and denuded of a coherent future. Disoriented in space and time, this person embodies a most severe emotional geography."

Thus, not only is the process of becoming a refugee an emotional experience manifested spatially and temporally, but so are the reception and integration processes (both centered on the idea of welcome) - not to speak of the potentially perennial feelings of alienation by unwelcomed individuals in their countries of asylum or resettlement. While refugees are objectified as the targets of abstract mappings and policy measures, what types of lived and practiced spaces are available for these displaced noncitizens in terms of their day-to-day emotional geography? Often, but not necessarily, asylum seekers and refugees pose a marginalized role in a receiving society particularly upon their arrival. Accordingly, many experience their lived space through largely negative emotions, which may lead to enclaved or secluded social existence and social or institutional mistrust (Lyytinen 2017). As regards the practiced everyday space, beginning to live as an unprivileged non-citizen in an unfamiliar society cannot but entail frequent reminders of one's outsiderness.

Apart from such bleak but often all-too-real prospects, we would like to suggest that both lived and practiced aspects of spatiality can play a key role not only in refugees' exclusion, but also in their integration (Munt 2012, 556). The essential question related to refugees' reception and integration is how they can turn their precarious local existence into something positive, enhancing trust as the prerequisite for the processes of integration. Given that a society's "full members" hardly anywhere merely consist of bigoted cultural protectionists, but also include attitudinally mixed or wavering people as well as those who altruistically invest their time and emotions on refugees (see above), in fortunate circumstances, the accumulation of encouraging experiences can pave the way for refugees' increased competence and practical involvement in the society's spatial operating (cf. Lefebvre 1974 [1991]).

Hence, we argue that it is largely through meaningful encounters in concrete places of emotional welcome by which the insecure and negative spaces can be transformed into "protection spaces" (Lyytinen 2013). In such potentially empowering places, the fundamentally relational socio-spatial nature of welcome is evident: both the acts and feelings of welcoming and being welcomed can serve to strengthen sense of belonging and integration. Despite living in exile, asylum seekers and refugees can for their part welcome the locals into meaningful dialogues and emotionally engaging relationships, particularly through sharing their bodily lived spatial narratives and biographical memories of cultural 
encounters. In our inevitably globalizing and multiculturalizing societies, the mutual sites of emotional welcome can in these ways gain in significance as the hubs of cultural mixing, creativity and job creation, or otherwise develop into active agents in local place-making, and in turn contribute to the progressive transformation of societies and people's attitudes towards tolerance.

As regards researchers' roles in all this, we strongly agree with Nick Gill in that it is paramount that we, as researchers, are among voices that seek to contribute to making our societies more welcoming for people seeking safe spaces with new beginnings. Resistance to unwelcome is a key to change.

\section{Notes}

${ }^{1}$ This policy change, and the consequent political pressure, has had substantial impacts on the asylum decisions in Finland ever since. In 2015, 86\% of young Iraqi asylum seekers received positive decisions on their asylum applications, whereas in 2017 79\% of them received negative decisions (Saarikkomäki et al. 2018). This dramatic proportional decrease cannot be solely explained by the amendments in the Finnish Aliens Act. Other institutional factors behind the negative asylum decisions include political pressure from the Government and attempts to harmonise the national procedures of granting international protection with other Nordic countries. Thus, the shift from welcome to unwelcome has not only occurred in Sipilä's public statements and the implemented immigration policy in Finland, but also on the transnational scale.

\section{References}

Boccagni, P. \& Baldassar, L. (2015) Emotions on the move: mapping the emergent field of emotions and migration. Emotions, Space and Society 1673-80.https://doi.org/10.1016/j.emospa.2015.06.009

Butler, C. (2012) Henri Lefebvre: Spatial Politics, Everyday Life and the Right to the City. Nomikoi: Critical Legal Thinkers. Routledge, Abington.

Christou, A. (2011) Narrating lives in (e)motion: embodied, belongingness and displacement in diasporic spaces of home and return. Emotion, Space and Society 4 249-257. https://doi.org/10.1016/j.emospa.2011.06.007

Davidson, J., Bondi, L. \& Smith, M. (2005) Emotional Geographies. Routledge, Abington.

Finnish Government (2015) The Government action plan on asylum policy, 8.12.2015. Finnish Government, Helsinki. <http://valtioneuvosto.fi/documents/10184/1058456/Hallituksen_ turvapaikkapoliittinen_toimenpideohjelma_08122015+EN.pdf/3e555cc4-ab01-46af-9cd4138b2ac5bad0/Hallituksen_turvapaikkapoliittinen_toimenpideohjelma_08122015+EN.pdf.pdf>

Foucault, M. (1990) The History of Sexuality. Volume 1. An Introduction. Translated by R. Hurley. Penguin Books, London.

Gill, N. (2018) The suppression of welcome. Fennia 196(1) 88-98. https://dx.doi.org/10.11143/ fennia.70040

Lefebvre, H. (1974 [1991]) Production de l'cspace [The Production of Space]. Translated by D. NicholsonSmith. Blackwell Publishing, Oxford.

Lyytinen, E. (2013) Spaces of trust and mistrust: Congolese refugees, institutions and protection in Kampala, Uganda. Unpublished DPhil thesis. School of Geography, University of Oxford, UK.

Lyytinen, E. (2017) Refugees' journeys of trust: creating an analytical framework to examine refugees exilic journeys with a focus on trust. Journal of Refugee Studies 30(4) 489-501. https://doi.org/10.1093/jrs/few035

Marshall, E., Pinkowska, P. \& Gill, N. (2016) Virtual presence as a challenge to immobility: examining the potential of an online anti-detention campaign. In Turner, J. \& Peters, K. (eds.) Carceral Mobilities, 133-146. Routledge, Abingdon.

McDowell, L. \& Sharp, J.P. (1999) A Feminist Glossary of Human Geography. Arnold, New York.

Merrifield, A. (2006) Henri Lefebvre: A Critical Introduction. Routledge, Abington.

Munt, S. R. (2012) Journeys of resilience: the emotional geographies of refugee women. Gender, Place \& Culture: A Journal of Feminist Geography 19(5) 555-577. https://doi.org/10.1080/0966369X.2011.610098

Reuters (2015) Finland's millionaire prime minister offers his home to refugees $6.9 .2015<\underline{\text { https:// }}$ www.reuters.com/article/us-europe-migrants-finland-pm/finlands-millionaire-prime-minister-offershis-home-to-refugees-idUSKCNOR507E20150906>. 27.04.2018. 
Russell Hochschild, A. (1983) The Managed Heart: Commercialization of Human Feeling. University of California Press, Berkeley.

Saarikkomäki, E., Oljakka, N., Vanto, J., Pirjatanniemi, E., Lavapuro, J., Alvesalo-Kuusi, A. (2018) Kansainvälistä suojelua koskevat päätökset Maahanmuuttovirastossa 2015-2017. Oikeustieteellisen tiedekunnan tutkimusraportteja ja katsauksia 1/2018. Turun yliopisto, Turku. <http://www. utu.fi/ filyksikot/law/tutkimus/katsauksia-ja-tutkimusraportteja/Documents/Kansainvalista\%20 suojelua\%20koskevat\%20paatokset\%20Maahanmuuttovirastossa\%2022.3.2018.pdf> 26.04.2018.

Shields, R. (1999) Lefebvre, Love and Struggle. Routledge, London.

Suurpää, L. (2002) Erilaisuuden hierarkiat: Suomalaisia käsityksiä maahanmuuttajista, suvaitsevaisuudesta ja rasismista. Nuorisotutkimusverkosto, Helsinki.

The Washington Post (2015) Finland's prime minister is offering his home to refugees 9.9.2015 $<$ https://www.washingtonpost.com/news/on-leadership/wp/2015/09/09/finlands-prime-minister-isoffering-his-home-to-refugees/?noredirect=on\&utm_term=.140ee78daa11>. 27.04.2018.

Vuolteenaho, J. (2001) Työn lopun kaupunki. Nordia Geographical Publications 30(3).

Vuolteenaho, J. (2010) Uusliberalisaatio ja kaupunkityöttömyyden arki Suomessa. Alue ja ympäristö 39(2) 69-78. https://aluejaymparisto.journal.fi/article/view/64483 